\title{
A generational investigation and sentiment and emotion analyses of female fashion brand users on Instagram in Sub-Saharan Africa
}

\author{
Ali B. Mahmoud ${ }^{1,2}$ (1) $\cdot$ Dieu Hack-Polay ${ }^{3,4} \cdot$ Nicholas Grigoriou $^{5} \cdot$ Iris Mohr $^{1} \cdot$ Leonora Fuxman $^{1}$
}

Revised: 21 April 2021 / Accepted: 3 June 2021 / Published online: 19 June 2021

(c) The Author(s), under exclusive licence to Springer Nature Limited 2021

\begin{abstract}
Renewed interest in gender-sensitive studies focussing on fashion brands marketing communications across diverse cultures and generational cohorts of consumers has heightened the need for uniqueness when developing marketing strategies for fashion brands in both domestic and international markets. Following that, we surveyed 1,329 Sub-Saharan African female Instagram users to investigate the mediating role of consumer satisfaction concerning the relationships between perceived usefulness, enjoyment and intentions to follow and recommend brands' Instagram accounts and their invariance across three generations. We tested hypotheses using the Partial-Least-Squares Structural Equation Modelling and conducted emotion and sentiment analyses. We found that satisfaction fully translates the positivity of usefulness and enjoyments into higher intention to follow and recommend amongst the female Instagram users surveyed. Usefulness effects on satisfaction are more intense amongst Generation X. However, Generation Z developed a stronger intention to follow. Generations Y and $\mathrm{Z}$ are more likely to recommend than Generation $\mathrm{X}$ based on a positive experience. Satisfaction is a stronger transmitter of usefulness indirect effects onto following intentions amongst Generation $\mathrm{X}$ than its descendants who express intention to recommend due to indirect enjoyment effects conveyed via satisfaction. Finally, sentiment and emotion analyses of the users' comments were reported using a natural language-processing method.
\end{abstract}

Ali B. Mahmoud

elguitarrista@live.com

1 St. John's University, New York, NY, USA

2 University of Wales Trinity Saint David, London, UK

3 Crandall University, Crandall, Canada

4 University of Lincoln, Lincoln, UK

5 Monash University, Victoria, Australia 


\section{Graphic abstract}
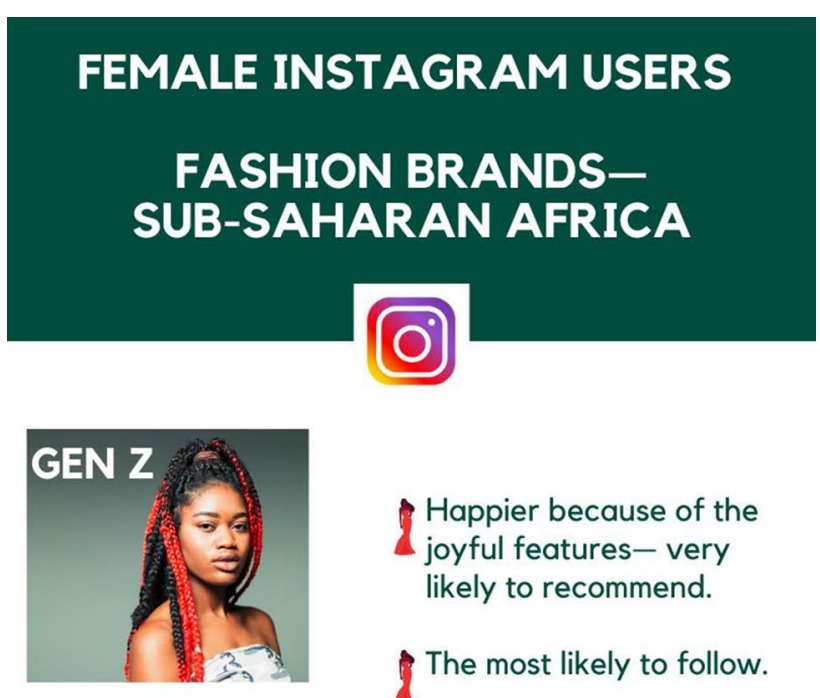

Happier because of the

joyful features- very likely to recommend.

The most likely to follow.

\section{Happier because of the 2 joyful features - the most generation likely to recommend.}
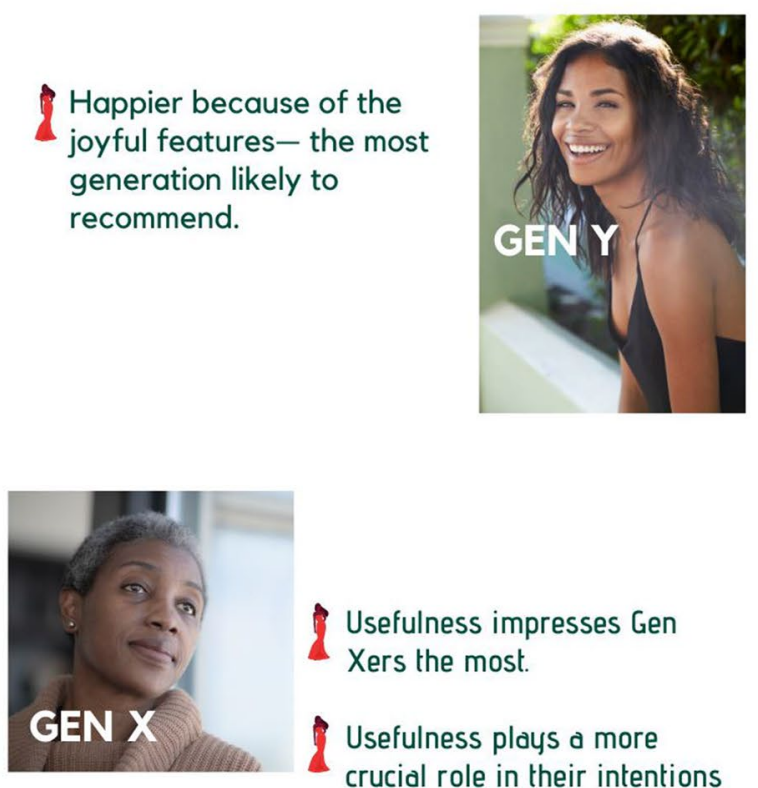

Usefulness impresses Gen

Xers the most.

Usefulness plays a more

crucial role in their intentions to follow than younger generations.
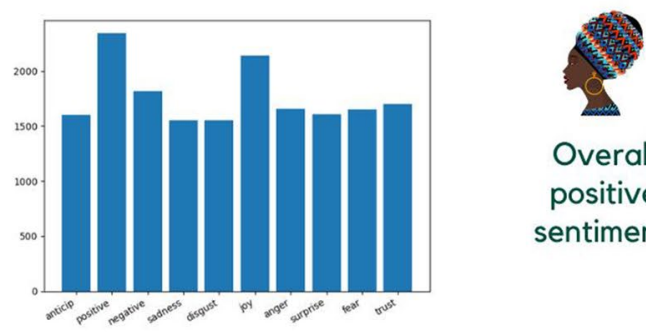

Overall positive sentiments

Keywords Social media marketing analytics · Instagram · Fashion · Attitudes · Consumer behaviour - Emotion analysis · Sentiment analysis $\cdot$ Female consumers $\cdot$ Sub-Saharan Africa 


\section{Introduction}

Social media platforms are increasingly used by individuals, both young and old, as a means of interacting with others. A significant number of people now use online platforms to obtain or convey information. Social media platforms are described as web-based services that enable individuals to build a public profile within a bordered system, articulate a catalogue of other users whom they have a shared connection with, and view and navigate through their list of connections (Boyd and Ellison 2007). Consumers are spending more and more time on social media platforms-an increasing share of communication occurs within these new social network environments (We Are Social, DataReportal et al 2021). Within this perspective, social media platforms, e.g. Facebook, Twitter and Instagram, have become part of people's daily lives. Instagram was created in 2010 and has rapidly risen to prominence due to extensive usage and popularity, especially amongst young people, where more than half the worldwide population of Instagram is 34 years of age or younger (Statista 2020).

The use of social media is not a recent phenomenon. Its widespread use in marketing has seen social media used to improve marketing communications in marketing strategy development (Hassan et al. 2015), in managing business-tobusiness relationships (Pascucci et al. 2018), and to identify the business value (Olanrewaju et al. 2020; Stockdale et al. 2012). Social media allows brands to connect with customers promptly, directly, with lower cost and higher efficiency than other traditional communication tools (Hassan et al. 2015). Social media products range from instant messaging to social media platforms that provide users with the means to communicate, connect and interact with each other and their mutual friends (Quesenberry 2020). Social media applications are intended to generate, initiate and spread new and evolving online information sources concerning users' experiences of using products, brands, services and/or issues by allowing them to upload on social media sites (Bianchi 2021; Tuten 2020). Despite this, scholars have reported a dearth of traditional theoretical viewpoints on the use of social media as a marketing tool (Alalwan et al. 2017). Even fewer studies have addressed generational differences in the use of social media marketing (Calvo-Porral and PesqueiraSanchez 2019).

Instagram is currently one of the fastest-growing online social media platforms and currently is home to more than 1.2 billion users-ranking 5th after Facebook, YouTube, WhatsApp and Facebook Messenger (We Are Social, Hootsuite et al. 2021). It is a platform where products are on display in audio and video forms. Studies showed that the rate at which people visit Instagram has increased compared to other similar social media platforms (Djafarova and Rushworth 2017). Businesses use Instagram due to the unique features (e.g. visual attractiveness and global popularity) that Instagram introduced in 2016. Accordingly, many companies started to switch their Instagram accounts from a personal profile to a business profile. This online mobile photograph-sharing application enables its users either publicly or privately, to share images and videos. Also, the content distribution on Instagram can be simultaneously crossshared through various linked social media sites, including Facebook, Twitter and Tumblr.

A critical function of Instagram enables the use of a contact button feature to allow potential users or followers to reach them quickly and even add links to Instagram stories. These stories may be in the form of photographs or videos and appear for $24 \mathrm{~h}$ after they are posted. Instagram can also be used to make creative stories in the form of tutorials about the possible uses of the products; the platform can also inform consumers about sales and giveaways.

In Nigeria, Instagram ranks third coming after Facebook and WhatsApp - with a penetration rate equal to $25 \%$. Further, $53 \%$ of social media users in Nigeria are Instagram users, of which the majority (60\%) are male (Statista 2019b), aged between 18 and 34 years (70\%) (Statista 2019a). These statistics provide a fertile ground for research into how brands can use the rapidly growing popularity of Instagram in Nigeria to grow their follower base. Further, research on micro-businesses in Nigeria reveals they are proliferating, representing 99 per cent of micro, small and medium enterprises (Kale 2019) and are increasingly using digital marketing as part of their business strategy (Eze et al. 2020). From an individual perspective, recent research suggests that one of the top digital marketing trends in Nigeria for 2019 is 17 million active mobile social users implying potential business opportunities to explore customers with mobile marketing using mobile advertising since 50 per cent of Nigeria's population use smartphones (Mkwizu Kezia 2019). However, these statistics showing Instagram users being predominantly the youth indicate that there are left-behind sections of society (older people) whose engagement with these latest technologies has been understudied although they are being a significant proportion of the market that companies target.

Despite the academic interest, little attention has been given to the use of Instagram and its relationship to brand followers (Casaló et al. 2017), particularly for female users in Africa. In that respect, our study fills a significant gap in generational inclusiveness in the digital marketplace (Ameen et al. 2021).

We adopt Ameen et al.'s (2021) assertion that, compared to millennials, Generation $\mathrm{Z}$ consumers are more likely to display different behavioural patterns when interacting with cutting-edge technologies. However, a solid understanding of differences in these generations' expectations and 
interaction with various cutting-edge technologies is still lacking (Ameen et al. 2021).

This study focuses on females due to the gender gap in digital use in Nigeria, which is biased towards males. Research has demonstrated gender differences in decision making by suggesting that women make more disadvantageous risk decisions than men (Villanueva-Moya and Expósito 2021). Our study, therefore, builds on the previous work and model of Casaló et al. (2017). This prompts our central research question: To what extent are there generational differences in Instagram usage between Generations $\mathrm{X}, \mathrm{Y}$ and $\mathrm{Z}$ of female users?

Extant literature on social media usage shows evidence of significant differences amongst different generations regarding social media usage (e.g. Calvo-Porral and PesqueiraSanchez 2019). Accordingly, the primary purpose of this study is to examine the moderating role of generational differences on a path model linking Instagram users' perceived usefulness and enjoyment of fashion brands' Instagram accounts to the intention to follow and recommend such accounts via satisfaction, amongst a sample of female Instagram users in Nigeria.

\section{Literature review and hypotheses}

Instagram has been a subject of interest to both practitioners and scholars (De Veirman et al. 2017), primarily because it is a fast-growing platform where organisations can advertise their products. From a branding perspective, consumers have more significant interaction with brands on Instagram compared to other platforms (Serafinelli 2018). Instagram signifies a viable social media platform for a wide range of consumer brands interested in boosting their reach to Instagram users (Sashittal and Jassawalla 2020). Increasingly, celebrities, artists and radio stations seal informal arrangements that include advertising and branding via Instagram (Ferguson and Greer 2018). This influences individuals' attitude towards visiting a brand t account. Once their followers are aware of their product acceptance through usage, they are bound to visit the Instagram account (McCormick 2016).

Using social media allows brand owners to promote and create public awareness of their brand (Kamboj \& Rahman, 2016). Social media popularity has influenced brand owners to engage in consumer marketing strategy. This is a form of engagement where brand owners take advantage of positive comments made about their brand on Instagram to market to would-be users of their brand. The value of social media platforms such as Instagram allows consumers to improve brand awareness, influence brand image and state their preferences for specific brands. Social media websites can be a source of social influence as consumers may embark on the perception and judgement of others in consumer decision making (Djafarova and Rushworth 2017; Lee et al. 2018; Ruiz-Mafe et al. 2018). From a marketing perspective, social behaviour and how consumers think have traditionally been disseminated by media such as television, radio, newspapers and magazines. However, social media has begun to replace traditional media's enduring and influential role on the consumer (Duffett Rodney 2017).

Previous research in this domain has focussed on consumers' interactive behaviour rather than how it influences users' intention to recommend and follow the official Instagram account (Casaló et al. 2016a, 2016b, 2017). Intention to recommend is perceived as significant in marketing because it does not lead to the actual purchase. It provides additional cues as to the customer preferences and route to a network of potential customers (Chang et al. 2017; Ha and Im 2012). Further, extant research work is based on how Instagram account owners present their message on the platform rather than the customer's perceived attitude towards using the brand account.

Perceived usefulness can be defined as the extent to which a technology can meet the desired needs of the user in achieving its set goals (Davis 1989) and shows that a user's perceptions about the potential benefits of using a technology engender a positive effect towards that technology (Davis et al. 1992). As a multidimensional construct, perceived usefulness has previously been examined to understand repurchase intentions (e.g. Moslehpour et al. 2018), mobile banking adoption (e.g. Giovanis et al. 2019), repurchase intentions via mobile commerce (e.g. Chi 2018) and online customer reviews (e.g. Felbermayr and Nanopoulos 2016). As such, perceived usefulness attributes intuitively apply to a social media context.

In the context of social media platforms, perceived usefulness occurs when the user finds the information on the Instagram account useful to make specific decisions (Basak and Calisir 2015). The usefulness of an Instagram account is instrumental in determining the levels of user satisfaction with the social media account (Alhabash and Ma 2017; Huang and Su 2018; Oliver 1981). As the information presented on Instagram is very diverse, people will show interest in an Instagram account and develop satisfaction based on the type and usefulness of the information accessed. Therefore, we hypothesise the following.

H1 Perceived usefulness of an Instagram account positively affects users' satisfaction with using the platform.

Perceived enjoyment, according to Casaló et al. (2017), represents the degree of pleasure or entertainment that a consumer derives from using goods or services. For example, if a consumer recognises the entertainment value of a social media account, it is reasonable that such a user would derive enjoyment from its use. Therefore, perceived enjoyment is 
a positive feeling that a consumer might experience when using new technologies (Cheah et al. 2020; Nayal and Pandey 2020; Van der Heijden 2004). Consumers are motivated when they find the time spent on a social media platform relaxing and as a way of managing boredom (Lee and $\mathrm{Ma}$ 2012). Perceived enjoyment is described as an outcome of an activity that a user engaged in at the end of a hard day's work to relax, meet with friends as well as share information (Lee and Ma 2012; Tuten 2020). For customers' continuous enjoyment on Instagram, the platform must continue to offer exciting and enjoyable activities that meet their desires (Seol et al. 2016). Thus, in the process of searching for information, consumers may also listen to and enjoy music.

Occasionally, brand owners may decide to post useful information on their account that does not relate to their product but assume to be useful information to the followers and users of the account (Tuten 2020). For example, the brand owner may decide to identify with new developments or breaking news related to burning issues in the global arena, which may be of immense interest to the account user. It may also provide information on the corporate social responsibility activities they have been part of in both audio and pictorial forms. These aspects influence the attitude of the users towards the brand account.

Apparel products brands use Instagram to showcase their exquisite fabrics worn by models. When people scroll through the account, they are expected to enjoy the visuals presented to them as they give the users ideas about what to wear (Jin and Ryu 2020). When there is consistency in the content they provide, people will derive a higher degree of enjoyment, and there is a greater chance that people elect to follow the Instagram account (Casaló et al. 2017). Another factor that can cause perceived enjoyment that would encourage people to follow is how Instagram posts are arranged on an account. People are usually drawn to creatively styled Instagram accounts or even simple, classic looks with colours matching but not clashing (Manovich 2016). This leads us to hypothesise:

H2 Perceived enjoyment of an Instagram account positively affects users' satisfaction from visiting that account.

Satisfaction can be significantly related to their intention of adopting the reviews shared by an online travel group when making their travel plans. Similarly, Instagram users satisfied with an apparel brand are expected to become followers of that brand's Instagram account (Casaló et al. 2017) and start engaging with it online. An example of such an engagement is seeing or being notified of the updates that the brand releases via Instagram. Further, satisfied users are expected to exchange values with the Instagram account by compensating the account for their positive experience and satisfaction using the account. Predominantly that can be embodied in the users' intention of recommending the account to their circles. This aligns with the Planned Behaviour Theory (PBT). In his view of PBT (Ajzen 1991; Casaló et al. 2016b), Ajzen (1991) argued that three key aspects determine intention towards a particular behaviour. The first centres on personal attitude towards the behaviour, i.e. the extent to which an individual has a positive or negative assessment of reality. The second concerns the perceived social pressure to adopt that behaviour, e.g. the expectations of an individual's family and social networks regarding the desirability of becoming a customer. The third element centres on apparent self-efficacy, which derives from the potential to become a customer. We, therefore, hypothesise that:

H3 Users' satisfaction with an Instagram fashion account positively affects users' intention to follow that account.

Due to limiting the mental processing capacity that they allot to making choices about their purchases, consumers look for ways to simplify their decision making (Van Der Merwe and Van Heerden 2009). Social media platforms allow consumers to exchange opinions and brand preferences (Araujo and Neijens 2012). The primary source of electronic word of mouth is opinion leaders (Shi and Wojnicki 2014). The concept of opinion leadership refers to an individual's ability to influence a social network. In the absence of online opinion leaders, consumers will revert to heuristics to determine which account(s) to follow on a social media platform (Nunes et al. 2018). One such heuristic is satisfaction. Customer satisfaction is an antecedent of positive word of mouth or recommendation (Tran and Strutton 2020). Accordingly, we posit:

H4 Users' satisfaction with an Instagram fashion account positively affects users' intention of recommending that account to other Instagram users.

In this study, the users of an apparel official Instagram account will always be moved to continue to visit the account as an outcome of their satisfaction if the owner of the account uploads new fabrics and provides information on how such fabrics can be used for different styles. Presenting their offering may be in musical form - a situation where the Instagram account owner plays the music of a famous artist when presenting their product. Once an individual finds the use of an Instagram account useful or enjoyable, it is hypothesised that the user will be satisfied and hence will follow and recommend the account. An individual can either enjoy the look of an Instagram account, a product previously gotten from that Instagram account or even the service provided through that Instagram account. When that occurs, the individual is encouraged to order more products, follow the account if they were previously unsure about following 
and recommending the Instagram account to other people, including family, friends and colleagues. Besides, posting fun videos showing how to use a product can influence people to recommend the account because whilst they enjoy it, they may be reminded of someone who may need the tutorial video and send it to that person, thereby indirectly recommending that Instagram account.

According to Alhabash and Ma (2017), in the case of purchasing apparel brands on Instagram, users must have found the Instagram brand account useful in terms of brand presentation and quality of pictures uploaded regularly to find new things that will stimulate their interest each time they visit the account. Users will find an Instagram brand account useful if the information available on the account is accurate, reliable, relevant, timely and detailed (Seol et al. 2016). Similar perceptions are formed when the users experience good customer service, such as receiving polite and prompt responses to questions asked or even receiving the same quality of the ordered product through the Instagram account. Such experiences signify that users find an Instagram account useful when it meets all their expectations and, as such, will be willing to follow and more likely to recommend the account to others.

The extent of perceived usefulness is derived from the brand account is related to the extent to which such a brand account will be recommended. Because of an online brand's usefulness, an endogenous attitude is formed, and consumer confidence to follow or recommend the site will increase (Alhabash and Ma 2017; Huang and Su 2018; Oliver 1981). Individuals who particularly enjoy viewing accounts would probably follow the account so that they can keep enjoying the posts being shown. Essentially, it is presumed that there is a positive indirect relationship, via satisfaction, between perceived satisfiers (i.e. usefulness and enjoyment) and the users' intentions to become followers of and recommend the Instagram account. Both usefulness and enjoyment of a brand's Instagram account are expected to positively affect the users' intention to recommend the account. In this case, the social network site signifies an idyllic tool used to create, share and recommend the content uploaded in a brand industry to other users interested in the content. Casaló et al. (2017) indicate that the level of users' satisfaction created due to the usefulness and enjoyment during their visit to an Instagram account would lead to their willingness to follow the site and possibly their engagement in spreading positive word of mouth. This is consistent with the theory of planned behaviour (PBT) - (Ajzen 1991; Casaló et al. 2016b). Accordingly, we hypothesise that:

H5: Users' satisfaction with a fashion apparel brand on Instagram mediates the path from perceived usefulness to users' intention to follow the brand and intention to recommend the brand to other consumers.
The advent of social media has opened the door for a new generation of consumers that are far savvier and expect to participate (i.e. interact with products) by providing their experience to other consumers (Kotler et al. 2021). In light of this, we extend the theory and findings posited by Casaló et al. (2016b) and Ajzen (1991), we also posit:

H6: Users' satisfaction with a fashion apparel brand on Instagram mediates the path from perceived entertainment to users' intention to follow and intention to recommend the brand to other consumers.

Mahmoud, Fuxman, et al. (2020) define a generation as a group of born individuals within one range of birth years and infers that the generational disparity is about how similaraged cohorts connect things, people and experiences. People of the same generation share and experience similar historical, social and cultural events that influence the development of their attitudes and values (Mahmoud, Reisel, et al. 2020). Previous research brings to light that generational cohorts report many variations in values and characteristics amongst each other, and that can impact the homogeneity of the attitudes and behaviours across generations (Mahmoud, Fuxman, et al. 2020). Recently, there has been renewed interest in investigating the moderating role generation on individuals' attitudes and behaviours towards technology and social media networks. For example, Calvo-Porral and PesqueiraSanchez (2019) found that Generation Y often uses Facebook for entertainment and hedonic purposes, whilst Generation $\mathrm{X}$ is mainly motivated by practical and knowledge quest. Recent evidence suggests that generational cohorts are conceptualised as moderators of hypothetical models in the social and behavioural science arena (e.g. Mahmoud, Reisel, et al. 2020). Moreover, that extends to investigations on the interaction with community-based social media like Facebook (e.g. Calvo-Porral and Pesqueira-Sanchez 2019) and, thus, Instagram. This leads us to hypothesise:

H7: Users' generation moderates the path from usefulness and entertainment to intention to follow the brand on Instagram through satisfaction

To understand the path from usefulness and entertainment to recommending the brand on Instagram through satisfaction, we again draw on the works of Calvo-Porral and Pesqueira-Sanchez (2019) and hypothesise:

H8: Users' generation moderates the path from usefulness and entertainment to recommend the brand on Instagram through satisfaction

Figure 1 shows the conceptual model, which illustrates H1-H8. Finally, we hypothesise four additional paths, i.e. usefulness to intention to follow; usefulness to intention to recommend as well as enjoyment to intention to follow and enjoyment to intention to recommend, in order to determine whether the mediations, if statistically evidenced, are full or partial (Baron and Kenny 1986; Carrión et al. 2017). 
Fig. 1 Conceptual model

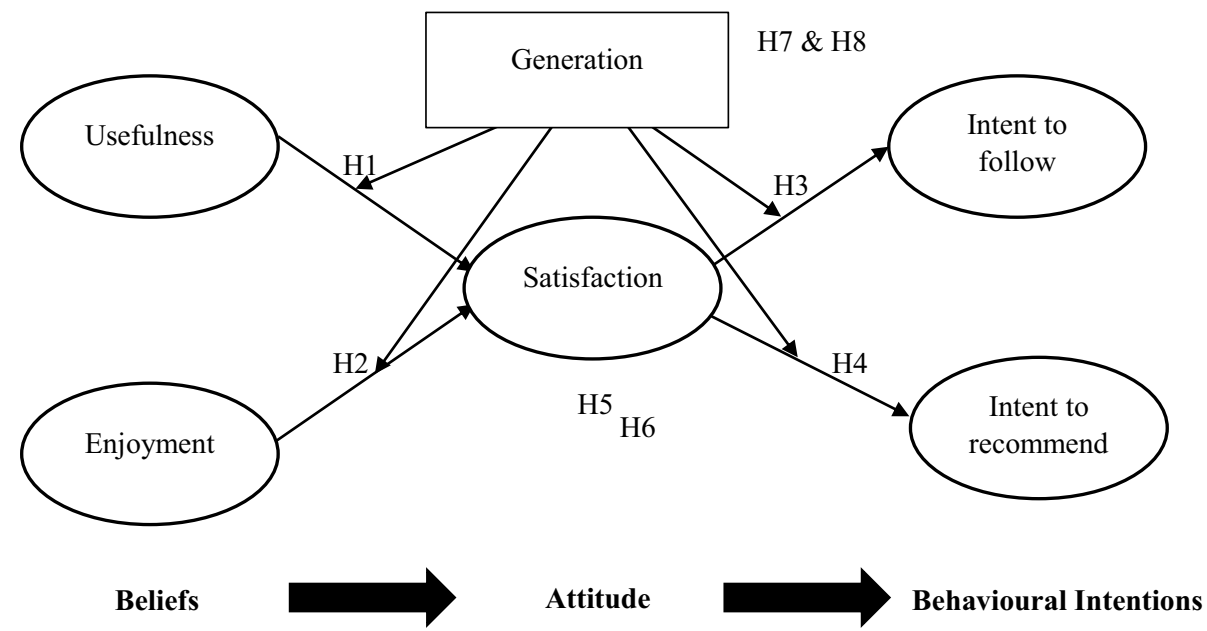

\section{Methods}

This study surveyed consumers who visited the website account of a fashion company with various innovative designs. The company is a leading Africa brand that specialises in African fabrics, hand-woven materials and bespoke clothing. The brand started operation in 1988 by joining an existing family business with a view to expanding the company to cover more contemporary design in the ever-developing and cosmopolitan high-brow society. At the time of conducting this study, the clothing brand had about 195,000 followers on its Instagram account with a similar presence on other social media sites.

Primary data were collected via an online questionnaire in 2019. It was administered to a convenience sample of 1,900 participants who visited the apparel brand account for fashion information as well as Instagram users who were aware of the brand account. Instagram was chosen as the online social media platform due to its popularity amongst young adults (Phua et al. 2017). A convenience snowball sampling method was utilised, and the respondents were approached through email and text messages. As this was through a snowball sampling process, in order to comply with the General Data Protection Regulation (GDPR), the researchers asked the first contacts to forward our contact email to people in their networks that might be willing to take part in the study; those needed to indicate a willingness by clicking on I wish to participate icon which sends an email to the surveyors who then contacted the potential respondents with fuller details of the study. They were informed ahead of the survey to determine their familiarity with the brand's Instagram account. Convenience snowball sampling was used because it would help us approach followers of the Instagram account with a substantial size of each generational cohort (Malhotra et al. 2017).

The survey used measures of usefulness, enjoyment, satisfaction and intention to recommend Instagram accounts adapted from Casaló et al. (2017). A total of 1329 respondents participated in the online survey. Thus, the study has a response rate of $70 \%$ of 1900 respondents initially proposed for the study. Consent to participate in the study was presented at the beginning of the survey. Since the survey was conducted online, the signatures of the participants were not obtained. In an introductory note in the questionnaire, we promised all participants the confidentiality and anonymity of their responses. To eliminate cases with missing data, we marked all of the questions as "Required". However, throughout the surveying process, all of the respondents were made aware of the aim and procedures of the research. They were permitted to ask questions, to raise issues about the survey, or withdraw from the study at any time. Thus, the procedure aimed for the avoidance of missing data rather than "forcing" the participants to respond. Also, our survey did not tap into personally sensitive questions (Sischka et al. 2020). Therefore, we argue that the low dropout rate (Stieger et al. 2007) represented by the high response rate of our survey (70\%) indicates that slight bias was associated with the force answering (FA) in the current study. Finally, online surveys are less susceptible to socially desirable responding (Gnambs and Kaspar 2015) because respondents do not have to share sensitive data in front of an interviewer (Sischka et al. 2020).

Overall, it took about 5-7 min to answer the questionnaire. All the responses collected were found usable for the analysis. We analysed non-response bias by comparing the earliest 50 respondents' scores with the latest fifty's (assuming late respondent behave the same as non-respondents) utilising an independent-sample $t$ test. All results yielded non-significant differences suggesting little non-response bias (Mahmoud and Grigoriou 2019). Most of the sample were Millennials (38\%), highly educated (62\%) and students or paid workers (71\%). "Appendix 1" demonstrates the constructs' descriptive statistics for the whole sample as well as for each generation. 
Table 1 Non-response bias test

\begin{tabular}{|c|c|c|c|}
\hline Construct & Item & $t$ & $P$ \\
\hline \multirow[t]{3}{*}{ Perceived Enjoyment } & Visiting this Instagram account entertains me and stimulates my mind & 0.77 & 0.442 \\
\hline & This Instagram account is funny and pleasant & 1.14 & 0.257 \\
\hline & I have great enjoyment when visiting this Instagram account & 0.24 & 0.811 \\
\hline \multirow[t]{3}{*}{ Perceived Usefulness } & Visiting this Instagram account helps me get suggestions about clothing & 1.02 & 0.308 \\
\hline & Visiting this Instagram account helps me get new ideas about fashion & 0.15 & 0.884 \\
\hline & In general, visiting this Instagram account is useful & 0.58 & 0.565 \\
\hline \multirow[t]{3}{*}{ Intention to Recommend } & I would likely recommend this Instagram account to friends and relatives interested in fashion & 0.49 & 0.628 \\
\hline & $\begin{array}{l}\text { I would seldom miss an opportunity to tell others interested in fashion about this Instagram } \\
\text { account on social networking sites }\end{array}$ & 1.34 & 0.184 \\
\hline & I would probably say positive things about this Instagram account on social networking sites & 0.16 & 0.871 \\
\hline \multirow[t]{2}{*}{ Satisfaction } & Overall, I'm satisfied with my experience with this Instagram account & 0.64 & 0.526 \\
\hline & Overall, I feel excited about visiting & 0.22 & 0.828 \\
\hline \multirow[t]{2}{*}{ Intention to Follow } & I predict that I will keep following this Instagram account & 0.58 & 0.565 \\
\hline & I will continue to look for new content published on this Instagram account & 0.86 & 0.393 \\
\hline
\end{tabular}

Table 2 Outer loadings, VIFs, construct reliability and validity and descriptive statistics

\begin{tabular}{lllllll}
\hline Item & Enjoyment & Intentions to Follow & $\begin{array}{l}\text { Intentions to } \\
\text { Recommend }\end{array}$ & Usefulness & Satisfaction & VIF \\
\hline enj01 & 0.732 & & & & 2.535 \\
enj02 & 0.932 & & & & 2.865 \\
enj03 & 0.886 & & & & 2.423 \\
if01 & & 0.845 & 0.779 & & & 1.767 \\
if02 & & & & & 1.767 \\
ir01 & & 0.761 & & 1.523 \\
ir02 & & & & & 1.523 \\
usf01 & & & 0.749 & & 1.639 \\
usf02 & & & 0.834 & & 2.606 \\
sat01 & & & & 0.740 & 1.515 \\
sat02 & & & & 0.788 & 1.515 \\
CR & 0.889 & 0.796 & 0.739 & 0.836 & 0.737 & \\
AVE & 0.730 & 0.661 & 0.586 & 0.724 & 0.584 & \\
Mean & 5.07 & 4.67 & 4.36 & 4.32 & 4.98 & \\
SD & 1.40 & 1.21 & 1.19 & 1.55 & 1.33 & \\
$t$ & $27.89 * *$ & $20.273^{* *}$ & $11.09^{* *}$ & $7.467^{* *}$ & $27.00^{* *}$ & \\
$d f$ & 1328 & 1328 & 1328 & 1328 & 1328 & \\
\hline
\end{tabular}

$* * P<.001$

\section{Measures and procedure}

Our study focussed on three generations. In that regard, we used the cut-offs identified in the influential demographic research of Coupland (1991), Inglehart (1997) and Mahmoud, Fuxman, et al. (2020). They classify the generations as: Generation X (1965-1981), Generation Y (1982-1999) and Generation Z (2000-2012). Since our data were collected in 2019, participants aged between 38 and 56 years were deemed Gen X, between 20 and 38 years, Gen $\mathrm{Y}$ and 19 or younger, Gen $\mathrm{Z}$.
All the multi-item measures (see Table 1) in this study were reflective and assessed on a 7-point Likert scale $(1=$ strongly disagree and $7=$ strongly agree $)$. Table 2 shows that all the constructs had average variance extracted (herein AVEs) higher than 0.5, CRs between 0.7 and 0.9 (Hair et al. 2017) and variance inflation factor (herein VIF) values less than 3 . We calculated the heterotrait-monotrait ratio of correlations (HTMT) - (see Table 3). Our results show values of less than 1 . This analysis suggests that all the measures used in the study satisfied the quality criteria of discriminant validity, construct reliability and convergent validity. Before proceeding with the path and multigroup analyses using a 
Table 3 Discriminant validity test (HTMT)

Table 4 Inner VIFs values

\begin{tabular}{lllll}
\hline & Enjoyment & $\begin{array}{l}\text { Intentions to } \\
\text { Follow }\end{array}$ & $\begin{array}{l}\text { Intentions to Rec- } \\
\text { ommend }\end{array}$ & Satisfaction \\
\hline Intentions to Follow & 0.812 & & & \\
Intentions to Recommend & 0.854 & 0.854 & 0.627 & \\
Satisfaction & 0.705 & 0.639 & 0.808 & 0.738 \\
Usefulness & 0.719 & 0.715 & 0.738 \\
\hline
\end{tabular}

\begin{tabular}{|c|c|c|c|c|c|}
\hline & Usefulness & Enjoyment & Satisfaction & $\begin{array}{l}\text { Intentions to } \\
\text { Follow }\end{array}$ & $\begin{array}{l}\text { Intentions to } \\
\text { Recommend }\end{array}$ \\
\hline Enjoyment & 2.977 & & & & \\
\hline Intentions to Follow & 2.062 & & & & \\
\hline Intentions to Recommend & 1.958 & & & & \\
\hline Satisfaction & 3.051 & & & & \\
\hline Intentions to Follow & & 1.84 & & & \\
\hline Intentions to Recommend & & 1.849 & & & \\
\hline Satisfaction & & 2.247 & & & \\
\hline Usefulness & & 2.462 & & & \\
\hline Enjoyment & & & 2.396 & & \\
\hline Intentions to Follow & & & 1.972 & & \\
\hline Intentions to Recommend & & & 2.015 & & \\
\hline Usefulness & & & 2.042 & & \\
\hline Enjoyment & & & & 1.962 & \\
\hline Intentions to Recommend & & & & 1.812 & \\
\hline Satisfaction & & & & 1.007 & \\
\hline Usefulness & & & & 1.494 & \\
\hline Enjoyment & & & & & 2.014 \\
\hline Intentions to Follow & & & & & 1.883 \\
\hline Satisfaction & & & & & 1.022 \\
\hline Usefulness & & & & & 1.493 \\
\hline
\end{tabular}

PLS-SEM approach via SmartPLS 3 (Ringle et al. 2015), we ran common-method bias (herein, CMB) tests, which are needed when using perceptual, self-report measures from a single survey (Podsakoff et al. 2003). The inner VIFs values (see Table 4) were all less than 3.3 (Kock 2015). Thus, there were no CMB concerns detected.

We scraped Instagram users' comments on the posts of the account shared during the time the participants were being surveyed. We used the scrapped data to conduct both emotional and sentimental analyses to determine the emotions as well as the overall sentiments triggered by the posts. Sentiment analysis signifies an alternative technique adept at triangulating quantitative methods through innovative real-time data collection and analysis (Rambocas and Gama 2013)_making more sense of the quantitative findings. We used "Instagram Scraper" developed by Hejlek (2019) to extract the account followers' comments. The crawling process returned 1,814 comments. We utilised Python 3.8.4 to perform emotion and sentimental analyses. We used "demoji" package to find and replace emojis within text strings, the Natural Language Toolkit (NLTK) to tokenise words and analyse the sentiments (Bird et al. 2009), and National Research Council Canada (NRC) Lexicons (NRCLex) to determine emotional affect from the scrapped text (Bailey 2019). Sentiment scores outwardly portray an objective means of evaluating the attitudes of social media users (Puschmann and Powell 2018). In this respect, running our code several times on the same scrapped data returned the same results, which implies our tool's reliability. Further, we argue that using open-source packages and libraries that are constantly developed and improved by experts in the field would substantiate the results validity of our sentiment and emotion analyses. "Appendix 2" shows the code we built to run both sentiment and emotion analyses. 
Table 5 Hypotheses testingdirect effects

\begin{tabular}{|c|c|c|c|c|c|}
\hline Hypothesis & Path & $\beta$ & $t$ & $\mathrm{f}^{2}$ & Decision \\
\hline H1 & Usefulness $\rightarrow$ Satisfaction & $0.375 * *$ & 5.568 & $\geq 0.20 * *$ & Supported \\
\hline $\mathrm{H} 2$ & Enjoyment $\rightarrow$ Satisfaction & $0.437 * *$ & 7.894 & $>0.20 * *$ & Supported \\
\hline $\mathrm{H} 3$ & Satisfaction $\rightarrow$ Intentions to Follow & $0.612 * *$ & 15.731 & $>0.50 * *$ & Supported \\
\hline $\mathrm{H} 4$ & Satisfaction $\rightarrow$ Intentions to Recommend & $0.608 * *$ & 14.479 & $>0.50^{* *}$ & Supported \\
\hline Additional path & Enjoyment $\rightarrow$ Intentions to Recommend & $0.152 *$ & 2.565 & $0.068^{N S}$ & Unsupported \\
\hline Additional path & Usefulness $\rightarrow$ Intentions to Recommend & $0.103^{N S}$ & 1.638 & $0.023^{N S}$ & Unsupported \\
\hline Additional path & Enjoyment $\rightarrow$ Intentions to Follow & $0.076^{N S}$ & 1.370 & $0.013^{N S}$ & Unsupported \\
\hline Additional path & Usefulness $\rightarrow$ Intentions to Follow & $0.271 *$ & 3.380 & $0.111^{N S}$ & Unsupported \\
\hline
\end{tabular}

Table 6 Hypotheses testingindirect effects

\begin{tabular}{lllll}
\hline Hypothesis & Path & B & STDEV & t \\
\hline H5 & Usefulness $\rightarrow$ Satisfaction $\rightarrow$ Intentions to Recommend & $0.229^{* *}$ & 0.048 & 4.743 \\
& Usefulness $\rightarrow$ Satisfaction $\rightarrow$ Intentions to Follow & $0.23^{* *}$ & 0.047 & 4.92 \\
H6 & Enjoyment $\rightarrow$ Satisfaction $\rightarrow$ Intentions to Recommend & $0.266^{* *}$ & 0.038 & 7.08 \\
& Enjoyment $\rightarrow$ Satisfaction $\rightarrow$ Intentions to Follow & $0.268^{* *}$ & 0.039 & 6.894 \\
\hline
\end{tabular}

$* * P<.001$

\section{Results}

We examined our hypotheses employing a PLS-SEM method. PLS-SEM has obtained more academic favourability when testing predictive models (Hair et al. 2014; Mahmoud, Reisel, et al. 2021). Also, most data are likely to violate the premise of multivariate normality (Mahmoud, Hack-polay, et al. 2020). Therefore, the PLSSEM approach has been recognised as a feasible option for empirical investigations where data are sensitive to nonnormality matters (Hair et al. 2017). In addition, PLS-SEM is receiving more recognition and implementation in brand management and marketing research (e.g. Akbar and Wymer 2017; Davies et al. 2021; Iyer et al. 2018; Mahmoud, Grigoriou, et al. 2020).

We ran a path evaluation followed by multigroup analysis (MGA), building on standardised betas ( $\beta$ : for direct effects), unstandardised betas (B: for indirect effects) and the corresponding $t$-values by using the bootstrapping method, PLSpredict to assess out-of-sample prediction and $\mathrm{f}^{2}$ to determine effect sizes (Hair et al. 2019). Further, SRMR was used to evaluate the model fit to our data (Henseler et al. 2014).

We performed Consistent PLS Algorithm, followed by Consistent PLS Bootstrapping run at 5,000 sub-samples (Preacher and Hayes 2008). Consequently, we found that both enjoyment $\left(\beta=0.44, P<0.001, \mathrm{f}^{2}>0.2\right)$ and usefulness $\left(\beta=0.38, P<0.001, \mathrm{f}^{2}>0.2\right)$ positively predict satisfaction which positively relates to Intentions to Recommend $\left(\beta=0.61, \mathrm{P}<0.001, \mathrm{f}^{2}>0.5\right)$ and Intentions to Follow $\left(\beta=0.61, P<0.001, \mathrm{f}^{2}>0.5\right)$. These statistics suggest that
$\mathrm{H} 1, \mathrm{H} 2, \mathrm{H} 3$ and $\mathrm{H} 4$ are valid (see Table 5). Table 6 shows that all the unstandardised betas are significant at a probability value less than 0.001 ; thus, we conclude that $\mathrm{H} 5$ and H6 are fully supported. Given that the additional hypothesised paths are not supported (see Table 5), this finding means that satisfaction fully mediates the relationship between enjoyment and intention to recommend, enjoyment and intention to follow, usefulness and intention to recommend and finally usefulness and intention to follow. Satisfaction plays the role of a full mediator that translates the positivity of an Instagram account's usefulness and enjoyment into female users being more likely to follow the account on Instagram and recommend it to others. Finally, with SRMR equal to $0.063<0.08$, we judge our hypothetical model fits the data well (Hu and Bentler 1999). Also, we compared the mean absolute error (MAE) and the root-mean-square error (RMSE) values with the LM value of each (Hair et al. 2019). The results (see Table 7) show that all of the observed variables in the PLS-SEM analysis score lower MAE and RMSE values compared to the naïve LM benchmark (Hair et al. 2019), offering evidence that our model has high predictive power (Shmueli et al. 2019).

Henseler et al. (2016) argue that conducting group comparisons through PLS-SEM can be "misleading" unless the invariance of their measures is substantiated. As recommended by Henseler et al. (2016), this prerequisite can be achieved by using the "Measurement Invariance of the Composite Models" (MICOM) procedure. Thus, before running any multigroup analyses (in our case: with no data pooling), both configural invariance and compositional 
Table 7 Predictive performance of the PLS model versus benchmark LM

\begin{tabular}{|c|c|c|c|c|}
\hline \multirow[t]{2}{*}{ Indicator } & \multicolumn{2}{|l|}{ PLS } & \multicolumn{2}{|l|}{ LM } \\
\hline & RMSE & MAE & RMSE & MAE \\
\hline if01 & 1.136 & 0.876 & 1.264 & 0.993 \\
\hline if02 & 1.392 & 1.161 & 1.458 & 1.223 \\
\hline ir01 & 1.090 & 0.804 & 1.152 & 0.920 \\
\hline ir02 & 1.207 & 0.901 & 1.326 & 1.065 \\
\hline $\mathrm{sa} 01$ & 0.556 & 0.428 & 0.654 & 0.484 \\
\hline $\mathrm{sa02}$ & 1.113 & 0.856 & 1.181 & 0.924 \\
\hline
\end{tabular}

Table 8 Compositional invariance assessment

\begin{tabular}{|c|c|c|c|c|}
\hline & $\begin{array}{l}\text { Original } \\
\text { correlation }\end{array}$ & $\begin{array}{l}\text { Correlation } \\
\text { permutation } \\
\text { mean }\end{array}$ & 0.050 & $\begin{array}{l}\text { Permu- } \\
\text { tation } \\
P \text {-Values }\end{array}$ \\
\hline \multicolumn{5}{|l|}{$\mathrm{X}$ versus $\mathrm{Y}$} \\
\hline Enjoyment & 0.999 & 0.999 & 0.997 & 0.320 \\
\hline Intentions to Follow & 1.000 & 0.997 & 0.991 & 0.660 \\
\hline $\begin{array}{l}\text { Intentions to Rec- } \\
\text { ommend }\end{array}$ & 0.999 & 0.995 & 0.982 & 0.479 \\
\hline Satisfaction & 1.000 & 0.999 & 0.995 & 0.984 \\
\hline Usefulness & 0.991 & 0.997 & 0.990 & 0.064 \\
\hline \multicolumn{5}{|l|}{$\mathrm{X}$ versus $\mathrm{Z}$} \\
\hline Enjoyment & 1.000 & 0.998 & 0.995 & 0.855 \\
\hline Intentions to Follow & 0.999 & 0.999 & 0.997 & 0.299 \\
\hline $\begin{array}{l}\text { Intentions to Rec- } \\
\text { ommend }\end{array}$ & 0.997 & 0.987 & 0.953 & 0.598 \\
\hline Satisfaction & 1.000 & 0.998 & 0.993 & 0.704 \\
\hline Usefulness & 0.999 & 0.986 & 0.946 & 0.752 \\
\hline \multicolumn{5}{|l|}{$\mathrm{Y}$ versus $\mathrm{Z}$} \\
\hline Enjoyment & 1.000 & 0.999 & 0.998 & 0.376 \\
\hline Intentions to Follow & 1.000 & 0.998 & 0.993 & 0.532 \\
\hline $\begin{array}{l}\text { Intentions to Rec- } \\
\text { ommend }\end{array}$ & 1.000 & 0.996 & 0.986 & 0.694 \\
\hline Satisfaction & 1.000 & 0.999 & 0.996 & 0.754 \\
\hline Usefulness & 0.999 & 0.996 & 0.985 & 0.635 \\
\hline
\end{tabular}

invariance need to be validated (Hair Jr et al. 2018; Henseler et al. 2016). Since we utilise a PLS-SEM method, the measurement configural invariance is, by default, attained (Hair Jr et al. 2018). Following that, we ran a permutation test (see Table 8). All of the constructs have their "Permutation $P$-values" greater than 0.05 ; thus, we accept the null hypothesis in the sense that the original correlations of these constructs are non-significantly different from 1 . This result offers supporting evidence of compositional invariance, suggesting a viable multigroup analysis (Hair Jr et al. 2018).

We ran a multigroup analysis (MGA) to assess the moderating effect of generational differences on the hypothesised path. Using the $t$-values associated with the multiple comparisons and reported in the parametric tests, we found three out of four of the proposed paths substantially not invariant across Generations X, Y and Z.

Figure 2 illustrates the moderated paths by generational differences where betas on the same side of a path arrow are non-significantly different. More detailed, Table 9 shows that although all of the paths remain sizably significant, Generation X's perceived usefulness effects on satisfaction $\left(\beta_{\mathrm{X}}=0.54, P<0.001\right)$ seem to be stronger than later generations $\left(\beta_{\mathrm{Y}}=0.31, P<0.001 ; \beta_{\mathrm{Z}}=0.31, P<0.001\right)$. However, Generation $\mathrm{Z}$ users $\left(\beta_{\mathrm{Z}}=0.66, P<0.001\right)$ appear to develop stronger intentions of following an Instagram account of a fashion brand when they feel satisfied with the experience of using such accounts than Generation $\mathrm{Y}\left(\beta_{\mathrm{Y}}=0.55\right.$; $P<0.001)$ and Generation $X\left(\beta_{X}=0.58, P<0.001\right)$. Further, our findings demonstrate that Generation $Y\left(\beta_{Y}=0.55\right.$, $P<0.001)$ seems to be more likely to recommend an Instagram account than Generation $\mathrm{X}\left(\beta_{\mathrm{X}}=0.42, P<0.001\right)$ based on positive usage experience. With significantly being invariant from their ancestors, however, Generation $\mathrm{Z}$ women $\left(\beta_{\mathrm{Z}}=0.50, P<0.001\right)$ looks, slightly, more similar to Generation $Y$ than Generation $X$ in terms of their tendency to recommend Instagram accounts based on pleasing user experience. Moreover, on the one hand, satisfaction tends to be stronger transmitter of the indirect effects of usefulness onto intentions to follow $\left(t_{\mathrm{x}, \mathrm{y}}=3.83, P<0.01\right.$; $\left.t_{\mathrm{x}, \mathrm{z}}=2.75>1.48, P<0.01 ; t_{y, z}=0.46<1.28, P>0.1\right)$ amongst Generation $\mathrm{X}\left(\mathrm{B}_{\mathrm{X}}=0.31, \mathrm{SD}=0.02, P<0.01\right)$ than their descendants $\left(\mathrm{B}_{\mathrm{Y}}=0.17, P<0.01, \mathrm{SD}=0.03 ; \mathrm{B}_{\mathrm{Z}}=0.20\right.$, $\mathrm{SD}=0.03, P<0.01)$. On the other hand, satisfaction serves as a more sizable mediator of enjoyment indirect effects on intention to recommend $\left(t_{\mathrm{x}, \mathrm{y}}=2.35>1.96, P<0.05\right.$; $\left.t_{\mathrm{x}, \mathrm{z}}=1.88>1.48, P<0.07 ; t_{y, z}=0.57<1.28, P>0.1\right)$ amongst Generation $\mathrm{Y}\left(\mathrm{B}_{\mathrm{Y}}=0.27, P<0.01, \mathrm{SD}=0.03\right)$ and Generation $\mathrm{Z}\left(\mathrm{B}_{\mathrm{Z}}=0.25, P<0.01, \mathrm{SD}=0.02\right)$ than Generation $\mathrm{X}\left(\mathrm{B}_{\mathrm{X}}=0.18, P<0.01, \mathrm{SD}=0.03\right)$. Thus, we conclude that $\mathrm{H} 7$ and $\mathrm{H} 8$ are partially supported.

Finally, Fig. 3 illustrates the emotion analysis results. It shows that the account posts triggered various emotions, of which positivity and joy were the most common reactions. Our sentiment analysis demonstrates that the account followers had an overall positive sentiment (61\%), whilst only $3 \%$ of the vibes were negative, and $36 \%$ were neutral. 
Fig. 2 Results of path model analysis

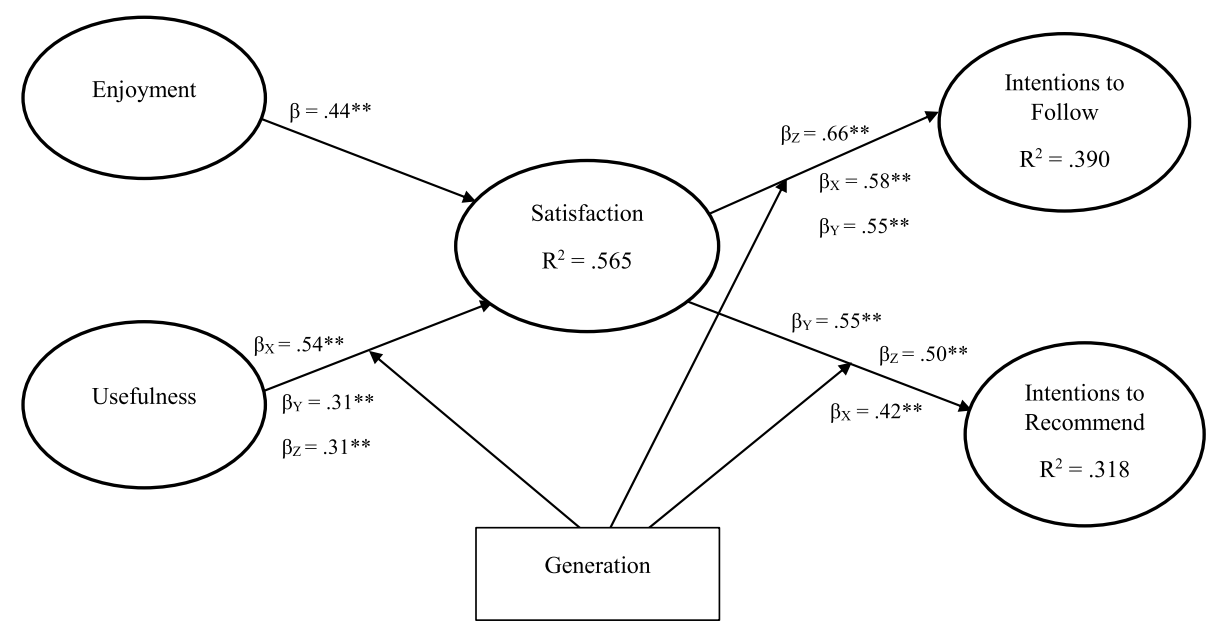

Table 9 Hypotheses 7 and 8 testing-multigroup invariance analysis

\begin{tabular}{|c|c|c|c|c|c|c|}
\hline Path & $\beta_{\mathrm{X}}$ & $\beta_{\mathrm{Y}}$ & $\beta_{\mathrm{Z}}$ & $\begin{array}{l}t \text {-Value (Generation X } \\
\text { versus Generation Y) }\end{array}$ & $\begin{array}{l}t \text {-Value (Generation X } \\
\text { versus Generation Z) }\end{array}$ & $\begin{array}{l}t \text {-Value (Generation Y } \\
\text { versus Generation Z) }\end{array}$ \\
\hline Enjoyment $\rightarrow$ Satisfaction & $0.429 * *$ & $0.497 * *$ & $0.498 * *$ & $1.317^{N S}$ & $1.238^{N S}$ & $0.014^{N S}$ \\
\hline Satisfaction $\rightarrow$ Intentions to Follow & $0.582 * *$ & $0.548 * *$ & $0.662 * *$ & $0.686^{N S}$ & $2.092 *$ & $2.837 * *$ \\
\hline Satisfaction $\rightarrow$ Intentions to Recommend & $0.424 * *$ & $0.545^{* *}$ & $0.504 * *$ & $2.079 *$ & $1.242^{N S}$ & $0.769^{N S}$ \\
\hline Usefulness $\rightarrow$ Satisfaction & $0.538 * *$ & $0.314 * *$ & $0.308 * *$ & $3.522 * *$ & $3.58 * *$ & $0.097^{N S}$ \\
\hline
\end{tabular}

$* P<.05 ; * * P<.01 ; N S$ : non-significant

Fig. 3 Results of emotion analysis

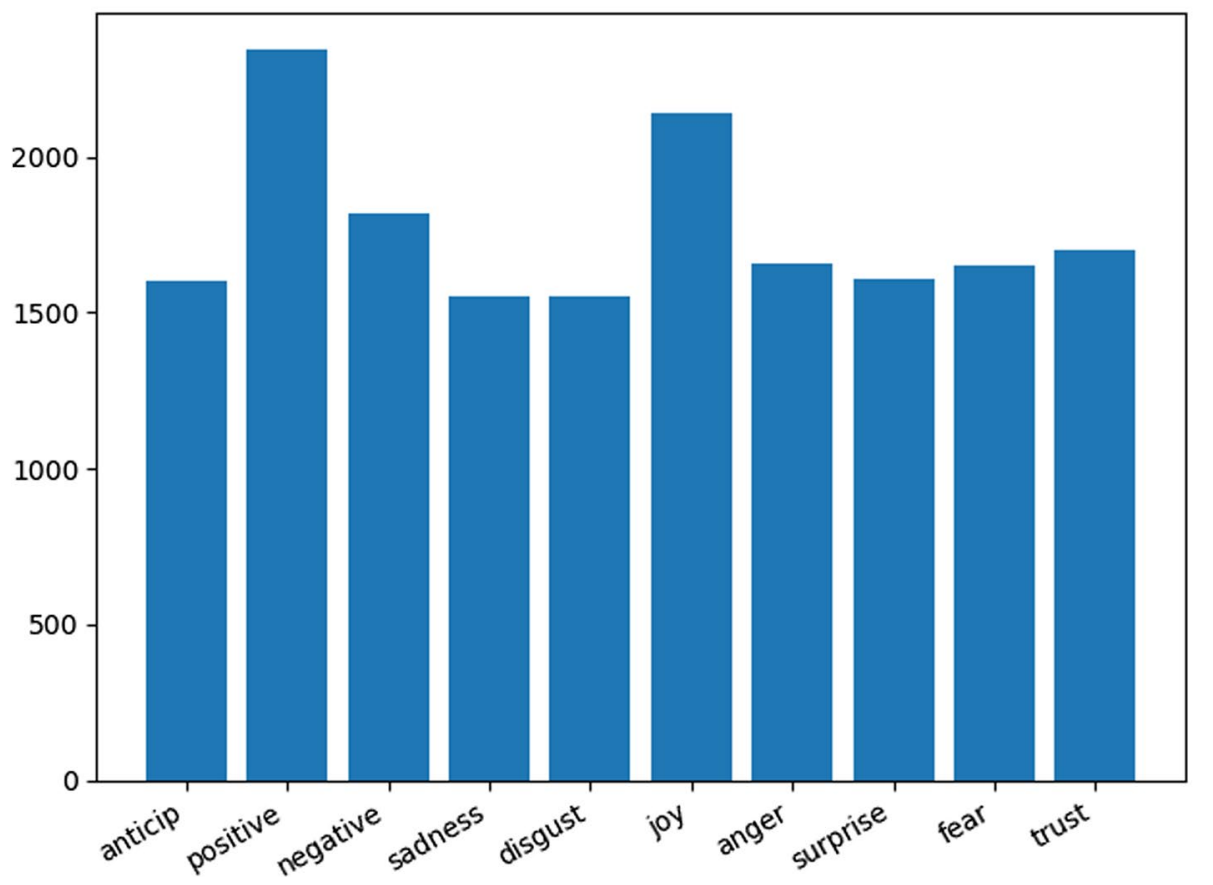




\section{Discussion}

The primary purpose of this research was to examine the moderating role of generation on relationships between perceived usefulness, enjoyment and intentions to follow and recommend brands' Instagram accounts for marketing. We, thus, tested a path model where perceived usefulness and enjoyment are hypothesised to indirectly predict Instagram female users' intentions to follow and/or recommend brand accounts that market apparel products on Instagram via those users' overall satisfaction as a result of their experience with such accounts in a Sub-Saharan African context, namely Nigeria. The analysis concluded that the perceived usefulness of the brand's Instagram account by the users is positively related to their intention to follow the brand Instagram account via satisfaction. The results are in line with previous research (Basak and Calisir 2015; Casaló et al. 2017; Davis 1989; De Matos and Rossi 2008; Lee and Ma 2012; Mitchell and Olson 1981; Oliver 1981; Van der Heijden 2004). However, we found that generation moderates the hypothesised model. In this regard, usefulness effects on satisfaction were found to be more intense amongst Generation $\mathrm{X}$ than later generations. Generation $\mathrm{Z}$ developed a stronger intention to follow than older generations. This finding helps marketing organisations better target different generational cohorts with unique (tailor-made) offers. Later generations, especially Generation Y, are more likely to recommend than Generation $\mathrm{X}$ based on a positive experience. This finding also has practical implications for marketers, especially when they try an influencer's positive word-ofmouth recommendations regarding their brand. They may target Generation Y users as brand ambassadors in a Nigerian social media setting. This finding is consistent with the work of Abdurrahaman and Osman (2017).

Satisfaction tends to be a more reliable transmitter of the indirect effects of usefulness onto intentions to follow amongst Generation $\mathrm{X}$ than its descendants who tend to have intentions to recommend due to indirect enjoyment effects conveyed via satisfaction. The investigated account posts were found to have caused emotions of happiness and joy amongst the followers whose comments revealed a prevalence of positive vibes. This finding is consistent with previous work that examined the positive effects of needs satisfaction on purchase intentions (see, for example, Wang et al. 2021).

Generational differences are also observed from the data. The closer the generations are to the year 2000, the more they appear to engage with online purchases, following Instagram and recommending it to others. It is not surprising that Generation $\mathrm{Z}$ is particularly more active in the social media milieus than their predecessors (CalvoPorral and Pesqueira-Sanchez 2019; Tayo et al. 2019). This demonstrates that Saharan Africa is becoming a significant emerging market for brands. The youthful population of the region makes it a fertile ground for social media marketing (Ngwainmbi 2019). The uptake of social media activities is growing amongst female users, with a significant increase in girls' schooling in Sub-Saharan Africa in the past two decades (Mbarika et al. 2007; Onyango-Obbo 2019).

\section{Conclusion, implications and limitations}

The research has examined the use of Instagram across three generations of women in Nigeria. The study found significant differences between Generations X, Y and Z, but Gen $\mathrm{X}$ lags significantly behind the latter generations in terms of their use of Instagram. Unlike longitudinal studies, we used a cross-sectional design with all data collected at one point in time. Although cross-sectional research has been accused of limited ability for proving causation (e.g. Langdridge 2004), it also has been argued (Spector 2019) that longitudinal design's ability to reflect causality has been exaggerated and that it only presents limited benefits over the cross-sectional design in most instances in which it is employed. Also, results from cross-sectional research can still be considered interpretable and valid, provided they are carried out on a sound theoretical basis (Tharenou et al. 2007; Mahmoud and Grigoriou 2019). Yet, we endorse further replications with a longitudinal design employed.

The age distribution of the respondents was skewed towards a younger population. This can affect what could be considered as measures of perceived usefulness and enjoyment (Mahmoud, Ekwere, et al. 2019). Also, the use of nonprobability sampling (convenience snowball) in this study may 
impinge on the generalisability of our results. Nevertheless, many survey procedures involve biases (e.g. non-response); as a result of this, the current inquiry interpretations are expected to be greater than the limitations linked to the sampling procedure (Mahmoud, Grigoriou, et al. 2019). Using force answering (FA) to reduce the amount of missing data could bring bias into the forced responses. Thus, we suggest that future research employs alternatives to FA. For instance, using "soft reminders" alongside offering a "Prefer not to answer" (Sischka et al. 2020) or "Not wish to disclose" as an additional option whilst responding to the questionnaire items could minimise missing data without elevating the risk of FA bias.

Further research should address whether user-generated brand (UGB) influences the attitude of individuals to follow and recommend a brand account. Research can also be conducted to analyse a situation where users of a brand account present or post information or pictures of another brand through their blog to friends in ways that change the quality of the post, either positively or negatively.

In addition, the generational cohorts examined in this study seldom use one platform for their social media interaction. Neither do market-driven organisations. Accordingly, future research can compare various social media platforms such as Facebook or Snapchat's ability to Influence consumers' perceptions of fashion brands.

Future research may extend to other visually appealing consumer goods (online) such as packaged food, travel or motor vehicles. Finally, given the rapid economic development occurring in Africa (Zahonogo 2016), future scholarly work may extend our study's scope to include industrialising African nations such as Cameroon, Ethiopia or Algeria. A significant endeavour that could expand our study is the consideration of a multigroup analysis, which would specifically contrast males and females to understand the forces favouring the former and causing a degree of digital exclusion for the latter.

This research scope was limited in terms of drawing upon data collected before the current pandemic (termed as SARS-CoV-2 or COVID-19) that has put the entire world into desperate straits. COVID-19's advent and its sweeping transformation of the political, social and economic panorama have offered a unique opportunity for scholars in every discipline to examine the "new normal" triggered by the pandemic - it signifies one of the most dramatic disruptions in contemporary marketing archives (Mahmoud, Hack-Polay, et al. 2021; Mahmoud, Grigoriou, et al. 2020). That could extend to the many facets of fashion brands management (Iglesias and Ind 2020; Wang et al. 2021), including the brand presence on social media and the potential shift in Instagram users' attitudes and behavioural patterns in that respect. Therefore, future research should concentrate on the investigation of how consumers' perceptions of COVID19 could impact the variables or moderate the relationships reported in this study.

\section{Appendix 1}

See Table 10.
Table 10 Constructs' descriptive statistics

\begin{tabular}{|c|c|c|c|c|c|c|c|c|}
\hline \multirow[t]{3}{*}{ Construct } & \multirow{2}{*}{\multicolumn{2}{|c|}{$\begin{array}{l}\text { Full sample } \\
(\mathrm{N}=1329)\end{array}$}} & & & \multirow{2}{*}{\multicolumn{2}{|c|}{$\begin{array}{l}\begin{array}{l}\text { Spilt based on } \\
\text { generation }\end{array} \\
\text { Gen } \mathrm{Y}(\mathrm{N}=499)\end{array}$}} & \multirow{2}{*}{\multicolumn{2}{|c|}{ Gen $X(N=370)$}} \\
\hline & & & \multicolumn{2}{|c|}{ Gen $Z(N=460)$} & & & & \\
\hline & Mean & STDV & Mean & STDV & Mean & STDV & Mean & STDV \\
\hline Enjoyment & 5.073 & 1.403 & 5.268 & 1.555 & 4.968 & 1.307 & 4.973 & 1.302 \\
\hline Usefulness & 4.673 & 1.210 & 4.902 & 1.179 & 4.499 & 1.179 & 4.622 & 1.245 \\
\hline Satisfaction & 4.363 & 1.192 & 4.505 & 1.241 & 4.230 & 1.139 & 4.365 & 1.182 \\
\hline Intentions to Follow & 4.318 & 1.550 & 4.337 & 1.647 & 4.054 & 1.511 & 4.649 & 1.411 \\
\hline Intentions to Recommend & 4.983 & 1.328 & 5.207 & 1.395 & 4.736 & 1.357 & 5.041 & 1.137 \\
\hline
\end{tabular}




\section{Appendix 2: Python code used in sentiment and emotional analyses}

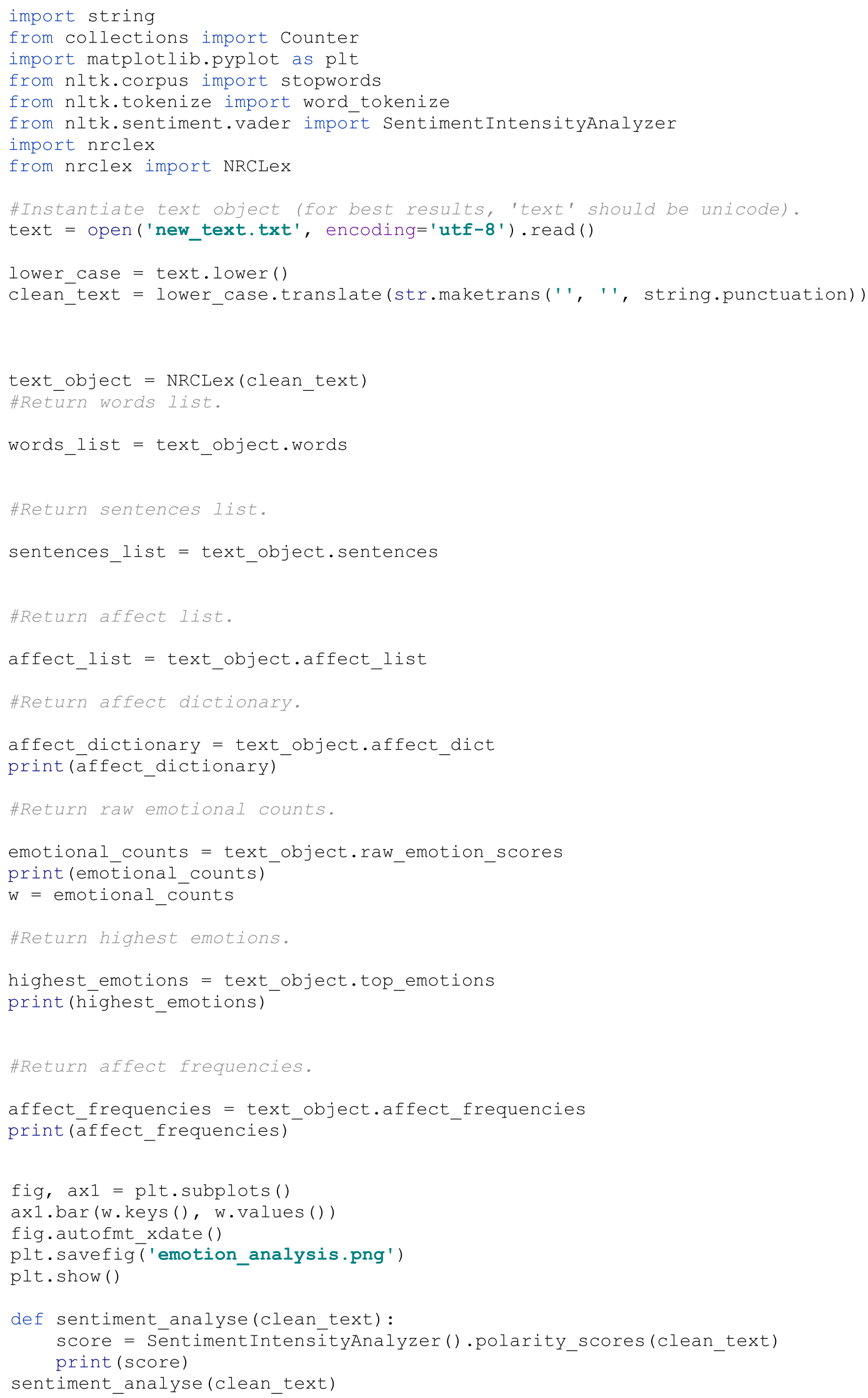


Author contribution Dieu Hack-Polay, Nicholas Grigoriou, Iris Mohr and Leonora Fuxman contributed equally to this article.

Funding No financial support was received for this research.

Data availability Data are available on request due to privacy/ethical restrictions.

\section{Declaration}

Conflict of interest The authors declare no conflict of interest.

\section{References}

Abdurrahaman, D.T., and Z. Osman. 2017. Development of conceptual framework for Nigerian generation Y-ers' purchase intention and response towards indigenous celebrity-endorsed products: A PLS-SEM Study on Selected Mobile Service Providers in Nigeria. Journal of Administrative and Business Studies 3 (1): 49-59.

Ajzen, I. 1991. The theory of planned behavior. Organizational Behavior and Human Decision Processes 50 (2): 179-211. https://doi. org/10.1016/0749-5978(91)90020-T.

Akbar, M.M., and W. Wymer. 2017. Refining the conceptualization of Brand Authenticity. Journal of Brand Management 24 (1): 14-32. https://doi.org/10.1057/s41262-016-0023-3.

Alalwan, A.A., N.P. Rana, Y.K. Dwivedi, and R. Algharabat. 2017. Social media in marketing: A review and analysis of the existing literature. Telematics and Informatics 34 (7): 1177-1190. https:// doi.org/10.1016/j.tele.2017.05.008.

Alhabash, S., and M. Ma. 2017. A tale of four platforms: Motivations and uses of Facebook, Twitter, Instagram, and Snapchat among college students? Social Media Society 3 (1): 2056305117691544.

Ameen, N., S. Hosany, and A. Tarhini. 2021. Consumer interaction with cutting-edge technologies: Implications for future research. Computers in Human Behavior 120: 106761. https://doi.org/10. 1016/j.chb.2021.106761.

Araujo, T., and P. Neijens. 2012. Friend me: Which factors influence top global brands participation in social network sites. Internet Research 22 (5): 626-640. https://doi.org/10.1108/1066224121 1271581.

Bailey, M. M. (2019). The Sentiment and Emotion Lexicons. National Research Council Canada (NRC). Retrieved 18 July from http:// sentiment.nrc.ca/lexicons-for-research/.

Baron, R.M., and D.A. Kenny. 1986. The moderator-mediator variable distinction in social psychological research: Conceptual, strategic, and statistical considerations. Journal of Personality and Social Psychology 51 (6): 1173.

Basak, E., and F. Calisir. 2015. An empirical study on factors affecting continuance intention of using Facebook. Computers in Human Behavior 48: 181-189.

Bianchi, A. 2021. Driving consumer engagement in social media: Influencing electronic word of mouth, 1 st ed. Routledge: New York.

Bird, S., E. Klein, and E. Loper. 2009. Natural language processing with Python: analyzing text with the natural language toolkit. O'Reilly Media, Inc.

Boyd, D.M., and N.B. Ellison. 2007. Social network sites: Definition, history, and scholarship. Journal of Computer-Mediated Coтmunication. 13 (1): 210-230. https://doi.org/10.1111/j.1083-6101. 2007.00393.x.

Calvo-Porral, C., and R. Pesqueira-Sanchez. 2019. Generational differences in technology behaviour: Comparing millennials and
Generation X. Kybernetes 49 (11): 2755-2772. https://doi.org/ 10.1108/K-09-2019-0598.

Carrión, G.C., C. Nitzl, and J.L. Roldán. 2017. Mediation analyses in partial least squares structural equation modeling: Guidelines and empirical examples. In Partial least squares path modeling, ed. H. Latan and R. Noonan, 173-195. Springer. https://doi.org/10. 1007/978-3-319-64069-3_8.

Casaló, L. V., Flavián, C., \& Ibáñez, S. (2016a). Antecedents of consumer interaction in Instagram XXVIII Congreso de Marketing AEMARK, Madrid.

Casaló, L.V., C. Flavián, and S. Ibáñez. 2016b. Consumer interaction in Instagram: The role of perceived hedonism and satisfaction 2016 Global Marketing Conference at Hong Kong. Global Alliance of Marketing \& Management Associations.

Casaló, L.V., C. Flavián, and I. Sergio. 2017. Antecedents of consumer intention to follow and recommend an Instagram account. Online Information Review 41 (7): 1046-1063.

Chang, S.E., W.-C. Shen, and C.-H. Yeh. 2017. A comparative study of user intention to recommend content on mobile social networks. Multimedia Tools and Applications 76 (4): 5399-5417. https:// doi.org/10.1007/s11042-016-3966-1.

Cheah, I., A.S. Shimul, J. Liang, and I. Phau. 2020. Consumer attitude and intention toward ridesharing. Journal of Strategic Marketing. https://doi.org/10.1080/0965254X.2020.1733050.

Chi, T. 2018. Understanding Chinese consumer adoption of apparel mobile commerce: An extended TAM approach. Journal of Retailing and Consumer Services 44: 274-284. https://doi.org/ 10.1016/j.jretconser.2018.07.019.

Coupland, D. 1991. Generation X: Tales for an accelerated culture. Martin's Press.

Davies, M.A.P., U. Golob, J. Kernstock, and S.M. Powell. 2021. Journal of brand management: Editorial guidelines and expectations of authors. Journal of Brand Management 28 (1): 1-7. https:// doi.org/10.1057/s41262-020-00217-3.

Davis, F.D. 1989. Perceived usefulness, perceived ease of use, and user acceptance of information technology. MIS Quarterly 13 (3): 319-340.

Davis, F.D., R.P. Bagozzi, and P.R. Warshaw. 1992. Extrinsic and intrinsic motivation to use computers in the workplace1. Journal of Applied Social Psychology 22 (14): 1111-1132. https:// doi.org/10.1111/j.1559-1816.1992.tb00945.x.

De. Matos, C.A., and C.A.V. Rossi. 2008. Word-of-mouth communications in marketing: A meta-analytic review of the antecedents and moderators. Journal of the Academy of Marketing Science 36 (4): 578-596.

De. Veirman, M., V. Cauberghe, and L. Hudders. 2017. Marketing through Instagram influencers: The impact of number of followers and product divergence on brand attitude. International Journal of Advertising 36 (5): 798-828.

Djafarova, E., and C. Rushworth. 2017. Exploring the credibility of online celebrities' Instagram profiles in influencing the purchase decisions of young female users. Computers in Human Behavior 68: $1-7$.

Duffett Rodney, G. 2017. Influence of social media marketing communications on young consumers' attitudes. Young Consumers 18 (1): 19-39. https://doi.org/10.1108/YC-07-2016-00622.

Eze, S.C., V.C.A. Chinedu-Eze, C.K. Okike, and A.O. Bello. 2020. Critical factors influencing the adoption of digital marketing devices by service-oriented micro-businesses in Nigeria: A thematic analysis approach. Humanities and Social Sciences Communications 7 (1): 90. https://doi.org/10.1057/ s41599-020-00580-1.

Felbermayr, A., and A. Nanopoulos. 2016. The Role of emotions for the perceived usefulness in online customer reviews. Journal of Interactive Marketing 36: 60-76. https://doi.org/10.1016/j. intmar.2016.05.004. 
Ferguson, D.A., and C.F. Greer. 2018. Visualizing a non-visual medium through social media: The semiotics of radio station posts on Instagram. Journal of Radio and Audio Media 25 (1): 126-141.

Giovanis, A., P. Athanasopoulou, C. Assimakopoulos, and C. Sarmaniotis. 2019. Adoption of mobile banking services: A comparative analysis of four competing theoretical models. International Journal of Bank Marketing 37 (5): 1165-1189. https://doi.org/ 10.1108/IJBM-08-2018-0200.

Gnambs, T., and K. Kaspar. 2015. Disclosure of sensitive behaviors across self-administered survey modes: A meta-analysis. Behavior Research Methods 47 (4): 1237-1259. https://doi.org/10. 3758/s13428-014-0533-4.

Ha, Y., and H. Im. 2012. Role of web site design quality in satisfaction and word of mouth generation. Journal of Service Management 23 (1): 79-96. https://doi.org/10.1108/09564231211208989.

Hair, J.F., G.T.M. Hult, C. Ringle, and M. Sarstedt. 2017. A primer on partial least squares structural equation modeling (PLS-SEM). Sage Publications.

Hair, J.F., C.M. Ringle, and M. Sarstedt. 2014. PLS-SEM: Indeed a silver bullet. Journal of Marketing Theory and Practice 19 (2): 139-152. https://doi.org/10.2753/mtp1069-6679190202.

Hair, J.F., J.J. Risher, M. Sarstedt, and C.M. Ringle. 2019. When to use and how to report the results of PLS-SEM. European Business Review 31 (1): 2-24. https://doi.org/10.1108/ebr-11-2018-0203.

Hair, J.F., Jr., M. Sarstedt, C.M. Ringle, and S.P. Gudergan. 2018. Advanced issues in partial least squares structural equation modeling. Sage Publications.

Hassan, S., S.Z.A. Nadzim, and N. Shiratuddin. 2015. Strategic use of social media for small business based on the AIDA Model. Procedia Social and Behavioral Sciences 172: 262-269. https:// doi.org/10.1016/j.sbspro.2015.01.363.

Hejlek, J. (2019, July, 2020). Instagram Scraper. Apify Technologies s.r.o./GitHub. Retrieved 08 July from https://github.com/gippy/ instagram-scraper.

Henseler, J., T.K. Dijkstra, M. Sarstedt, A. Diamantopoulos, D.W. Straub, D.J. Ketchen, J.F. Hair, G.T.M. Hult, and R.J. Calantone. 2014. Common beliefs and reality about partial least squares: Comments. Rönkkö and Evermann Organizational Research Methods 17 (2): 182-209.

Henseler, J.R., R.-J.B.J. Sinkovics, R. Daekwan Kim, C.M. Ringle, and M. Sarstedt. 2016. Testing measurement invariance of composites using partial least squares. International Marketing Review 33 (3): 405-431. https://doi.org/10.1108/imr-09-2014-0304.

Hu, L.-T., and P.M. Bentler. 1999. Cutoff criteria for fit indexes in covariance structure analysis: Conventional criteria versus new alternatives. Structural Equation Modeling A Multidisciplinary Journal 6 (1): 1-55.

Huang, Y.-T., and S.-F. Su. 2018. Motives for Instagram use and topics of interest among young adults. Future Internet 10 (8): 77.

Iglesias, O., and N. Ind. 2020. Towards a theory of conscientious corporate brand co-creation: The next key challenge in brand management. Journal of Brand Management 27 (6): 710-720. https:// doi.org/10.1057/s41262-020-00205-7.

Inglehart, R. 1997. Modernization and postmodernization: Cultural, economic, and political change in 43 societies. Princeton University Press.

Iyer, P., A. Davari, and A. Paswan. 2018. Determinants of brand performance: The role of internal branding. Journal of Brand Management 25 (3): 202-216. https://doi.org/10.1057/ s41262-018-0097-1.

Jin, S.V., and E. Ryu. 2020. "I'll buy what she's \#wearing": The roles of envy toward and parasocial interaction with influencers in Instagram celebrity-based brand endorsement and social commerce. Journal of Retailing and Consumer Services 55: 102121. https:// doi.org/10.1016/j.jretconser.2020.102121.
Kale, Y. (2019). Micro, small, and medium enterprises (MSME) national survey 2017 report. National Bureau of Statistics. Retrieved 25 October from http://www.nigerianstat.gov.ng/downl oad/967.

Kamboj, S., and Z. Rahman. 2016. The influence of user participation in social media-based brand communities on brand loyalty: Age and gender as moderators. Journal of Brand Management 23 (6): 679-700. https://doi.org/10.1057/s41262-016-0002-8.

Kock, N. 2015. Common method bias in PLS-SEM: A full collinearity assessment approach. International Journal of e-Collaboration (ijec) 11 (4): 1-10.

Kotler, P., H. Kartajaya, and I. Setiawan. 2021. Marketing 5.0: Technology for humanity. Wiley.

Langdridge, D. 2004. Introduction to research methods and data analysis in psychology. Pearson Education Limited.

Lee, J.E., S. Hur, and B. Watkins. 2018. Visual communication of luxury fashion brands on social media: Effects of visual complexity and brand familiarity. Journal of Brand Management 25 (5): 449-462. https://doi.org/10.1057/s41262-018-0092-6.

Lee, S., and L. Ma. 2012. News sharing in social media: The effect of gratifications and prior experience. Computers in Human Behavior 28 (2): 331-339.

Mahmoud, A.B., T. Ekwere, L. Fuxman, and A.A. Meero. 2019. Assessing Patients' Perception of Healthcare Service Quality Offered by Private Healthcare Organisations in Nigeria. SAGE Open 9 (2): 1-9. https://doi.org/10.1177/2158244019852480.

Mahmoud, A.B., L. Fuxman, I. Mohr, W.D. Reisel, and N. Grigoriou. 2020. "We aren't your reincarnation!" workplace motivation across $\mathrm{X}, \mathrm{Y}$ and $\mathrm{Z}$ generations. International Journal of Manpower 42 (1): 193-209. https://doi.org/10.1108/ ijm-09-2019-0448.

Mahmoud, A.B., and N. Grigoriou. 2019. Modelling parents' unhealthy food choices for their children: The moderating role of child food allergy and implications for health policy. Journal of Family Studies 1-19. https://doi.org/10.1080/13229400.2019.1682642.

Mahmoud, A.B., N. Grigoriou, L. Fuxman, D. Hack-Polay, F.B. Mahmoud, E. Yafi, and S. Tehseen. 2019. Email is evil! Journal of Research in Interactive Marketing 13 (2):227-248. https://doi. org/10.1108/jrim-09-2018-0112.

Mahmoud, A.B., N. Grigoriou, L. Fuxman, W.D. Reisel, D. HackPolay, and I. Mohr. 2020. A generational study of employees' customer orientation: A motivational viewpoint in pandemic time. Journal of Strategic Marketing 1-18. https://doi.org/10. 1080/0965254x.2020.1844785.

Mahmoud, A.B., D. Hack-Polay, L. Fuxman, B. Massetti, and A.Z. Al Samarh. 2020. Developing and validating a new multi-dimensional scale for anti-social behavior in a higher education setting. Scandinavian Journal of Psychology 61 (4):502-512. https://doi. org/10.1111/sjop.12635.

Mahmoud, A.B., D. Hack-Polay, L. Fuxman, and M. Nicoletti. 2021. The Janus-faced effects of COVID-19 perceptions on family healthy eating behavior: Parent's negative experience as a mediator and gender as a moderator. Scandinavian Journal of Psychology. https://doi.org/10.1111/sjop.12742.

Mahmoud, A.B., W.D. Reisel, N. Grigoriou, L. Fuxman, and I. Mohr. 2020. The reincarnation of work motivation: Millennials vs older generations. International Sociology 35 (4):393-414. https://doi. org/10.1177/0268580920912970.

Mahmoud, A.B., W.D. Reisel, L. Fuxman, and I. Mohr. 2021. A motivational standpoint of job insecurity effects on organizational citizenship behaviors: A generational study. Scandinavian Journal of Psychology 62 (2):267-275. https://doi.org/10.1111/sjop. 12689.

Malhotra, N.K., D. Nunan, D.F. Birks, and P. Wills. 2017. Marketing research: An applied orientation. Pearson Education Limited. 
Manovich, L. 2016. Instagram and contemporary image. Manovich. net.

Mbarika, V.W.A., F.C. Payton, L. Kvasny, and A. Amadi. 2007. IT education and workforce participation: A New Era for women in Kenya? The Information Society 23 (1): 1-18. https://doi.org/ $10.1080 / 01972240601057213$.

McCormick, K. 2016. Celebrity endorsements: Influence of a productendorser match on millennial attitudes and purchase intentions. Journal of Retailing and Consumer Services 42: 39-45.

Mitchell, A., and J.C. Olson. 1981. Are product beliefs the only mediator of advertising effect on brand attitude? Journal of Marketing Research 18: 318-332.

Mkwizu Kezia, H. 2019. Digital marketing and tourism: Opportunities for Africa. International Hospitality Review 34 (1): 5-12. https:// doi.org/10.1108/IHR-09-2019-0015.

Moslehpour, M., V.K. Pham, W.-K. Wong, and İ Bilgiçli. 2018. e-Purchase intention of taiwanese consumers: Sustainable mediation of perceived usefulness and perceived ease of use. Sustainability. https://doi.org/10.3390/su10010234.

Nayal, P., and N. Pandey. 2020. Framework for measuring usage intention of digital coupons: A SPADM approach. Journal of Strategic Marketing. https://doi.org/10.1080/0965254X.2020.1777460.

Ngwainmbi, E. K. (2019). Social Media Use Among the Youth and Working Class: Conditions for Remediating Globalization and Cultural Space. In Media in the Global Context (pp. 49-93). Springer.

Nunes, R.H., J.B. Ferreira, A.S.D. Freitas, and F.L. Ramos. 2018. Efeitos das recomendações de líderes de opinião em mídias sociais sobre a intenção de compra de seus seguidores. Revista Brasileira de Gestão de Negócios 20 (1): 57-73. https://doi.org/10. 7819/rbgn.v20i1.3678.

Olanrewaju, A.-S.T., M.A. Hossain, N. Whiteside, and P. Mercieca. 2020. Social media and entrepreneurship research: A literature review. International Journal of Information Management 50: 90-110. https://doi.org/10.1016/j.ijinfomgt.2019.05.011.

Oliver, R.L. 1981. Measurement and evaluation of satisfaction processes in retail settings. Journal of Retailing 57 (3): 25-48.

Onyango-Obbo, C. 2019. Technology is a liberating force for african women. Africa Renewal 33 (1): 12-13.

Pascucci, F., C. Ancillai, and S. Cardinali. 2018. Exploring antecedents of social media usage in B2B: A systematic review. Management Research Review 41 (6): 629-656. https://doi.org/10.1108/ MRR-07-2017-0212.

Phua, J., S.V. Jin, and J. Kim. 2017. Gratifications of using Facebook, Twitter, Instagram, or Snapchat to follow brands: The moderating effect of social comparison, trust, tie strength, and network homophily on brand identification, brand engagement, brand commitment, and membership intention. Telematics and Informatics 34 (1): 412-424. https://doi.org/10.1016/j.tele.2016.06. 004.

Podsakoff, P.M., S.B. MacKenzie, J.Y. Lee, and N.P. Podsakoff. 2003. Common method biases in behavioral research: A critical review of the literature and recommended remedies. Journal of Applied Psychology 88 (5): 879-903. https://doi.org/10.1037/0021-9010. 88.5.879.

Preacher, K.J., and A.F. Hayes. 2008. Asymptotic and resampling strategies for assessing and comparing indirect effects in multiple mediator models. Behavior Research Methods 40 (3): 879-891. https://doi.org/10.3758/brm.40.3.879.

Puschmann, C., and A. Powell. 2018. Turning words into consumer preferences: How sentiment analysis is framed in research and the news media. Social Media Society 4 (3): 2056305118797724. https://doi.org/10.1177/2056305118797724.

Quesenberry, K.A. 2020. Social media strategy: Marketing, advertising, and public relations in the consumer revolution. Rowman $\&$ Littlefield Publishers.
Rambocas, M., \& Gama, J. (2013). Marketing research: The role of sentiment analysis.

Ringle, C. M., Wende, S., \& Becker, J.-M. (2015). SmartPLS 3. In (Version 3.2.8) SmartPLS GmbH. http://www.smartpls.com.

Ruiz-Mafe, C., E. Bigne-Alcañiz, S. Sanz-Blas, and J. Tronch. 2018. Does social climate influence positive eWOM? A study of heavyusers of online communities. BRQ Business Research Quarterly 21 (1): 26-38. https://doi.org/10.1016/j.brq.2017.12.001.

Sashittal, H.C., and A.R. Jassawalla. 2020. The personal influence of Instagram bloggers on consumer-brand interactions: Brands as tribal artifacts. Journal of Brand Management 27 (6): 679-690. https://doi.org/10.1057/s41262-020-00203-9.

Seol, S., H. Lee, J. Yu, and H. Zo. 2016. Continuance usage of corporate SNS pages: A communicative ecology perspective. Information and Management 53 (6): 740-751.

Serafinelli, E. 2018. Digital life on Instagram: New social communication of photography. Emerald Group Publishing.

Shi, M., and A.C. Wojnicki. 2014. Money talks ... to online opinion leaders. Journal of Advertising Research 54 (1): 81. https://doi. org/10.2501/JAR-54-1-081-091.

Shmueli, G., M. Sarstedt, F. Hair Joseph, J.-H. Cheah, H. Ting, S. Vaithilingam, and M. Ringle Christian. 2019. Predictive model assessment in PLS-SEM: Guidelines for using PLSpredict. European Journal of Marketing 53 (11): 2322-2347. https://doi.org/ 10.1108/EJM-02-2019-0189.

Sischka, P.E., J.P. Décieux, A. Mergener, K.M. Neufang, and A.F. Schmidt. 2020. The impact of forced answering and reactance on answering behavior in online surveys. Social Science Computer Review. https://doi.org/10.1177/0894439320907067.

Spector, P.E. 2019. Do not cross me: Optimizing the use of crosssectional designs. Journal of Business and Psychology 34 (2): 125-137. https://doi.org/10.1007/s10869-018-09613-8.

Statista. (2019a). Distribution of Instagram users in Nigeria as of June 2019, by age group [Graph]. Retrieved 28 October from https:// www.statista.com/statistics/1028396/nigeria-instagram-user-agedistribution/.

Statista. (2019b). Distribution of Instagram users in Nigeria as of June 2019, by gender [Graph]. Statista. Retrieved 28 October from https://www.statista.com/statistics/1028407/instagram-usershare-in-nigeria/.

Statista. (2020). Distribution of Instagram users worldwide as of April 2020, by age and gender. Retrieved 19 June from https://www. statista.com/statistics/248769/age-distribution-of-worldwideinstagram-users/.

Stieger, S., U.-D. Reips, and M. Voracek. 2007. Forced-response in online surveys: Bias from reactance and an increase in sex-specific dropout. Journal of the American Society for Information Science and Technology 58 (11): 1653-1660. https://doi.org/10. 1002/asi.20651.

Stockdale, R., Ahmed, A., \& Scheepers, H. (2012, 2012). Identifying business value from the use of social media: An SME perspective. In The 16th Pacific Asia conference on information systems, PACIS.

Tayo, S.S., S.T. Adebola, and D.O. Yahya. 2019. Social media: Usage and influence on undergraduate studies in Nigerian Universities. International Journal of Education and Development Using Information and Communication Technology 15 (3): 53-62.

Tharenou, P., R. Donohue, and B. Cooper. 2007. Management research methods. Cambridge University Press.

Tran, G.A., and D. Strutton. 2020. Comparing email and SNS users: Investigating e-servicescape, customer reviews, trust, loyalty and E-WOM. Journal of Retailing and Consumer Services 53: 101782. https://doi.org/10.1016/j.jretconser.2019.03.009.

Tuten, T.L. 2020. Social Media Marketing, 4th ed. SAGE Publications, Limited. 
Van der Heijden, H. 2004. User acceptance of hedonic information systems. MIS Quarterly 28 (4): 695-704.

Van Der Merwe, R., and G. Van Heerden. 2009. Finding and utilizing opinion leaders: Social networks and the power of relationships. South African Journal of Business Management 40 (3): a545. https://doi.org/10.4102/sajbm.v40i3.545.

Villanueva-Moya, L., and F. Expósito. 2021. Gender differences in decision-making: The effects of gender stereotype threat moderated by sensitivity to punishment and fear of negative evaluation. Journal of Behavioral Decision Making. https://doi.org/10.1002/ bdm.2239.

Wang, P., A.T.H. Kuah, Q. Lu, C. Wong, K. Thirumaran, E. Adegbite, and W. Kendall. 2021. The impact of value perceptions on purchase intention of sustainable luxury brands in China and the UK. Journal of Brand Management. https://doi.org/10.1057/ s41262-020-00228-0.
We Are Social, DataReportal, \& Hootsuite. (2021). Daily time spent on social networking by internet users worldwide from 2012 to 2020 (in minutes) [Graph]. Statista. Retrieved 19 April from https://www.statista.com/statistics/433871/daily-social-mediausage-worldwide/.

We Are Social, Hootsuite, \& DataReportal. (2021). Most popular social networks worldwide as of January 2021, ranked by number of active users (in millions) [Graph]. Statista. Retrieved 19 April from https://www.statista.com/statistics/272014/globalsocial-networks-ranked-by-number-of-users/.

Zahonogo, P. 2016. Trade and economic growth in developing countries: Evidence from sub-Saharan Africa. Journal of African Trade 3 (1): 41-56. https://doi.org/10.1016/j.joat.2017.02.001.

Publisher's Note Springer Nature remains neutral with regard to jurisdictional claims in published maps and institutional affiliations. 